\title{
Lymphokine activated killer (LAK) cells in patients with gastrointestinal cancer
}

\author{
J R T MONSON, C W RAMSDEN, G R GILES, T G BRENNAN, \\ AND P J GUILLOU \\ From the Department of Surgery, St James's University Hospital, Leeds
}

SUMMARY Lymphokine activated killer (LAK) cells are a recently described cellular immune phenomenon with exciting potential for the treatment of tumours arising from solid organs. A comparison of some aspects of LAK cell precursors and LAK cell function was undertaken in 44 control subjects and 44 preoperative patients suffering from gastrointestinal cancer (20 localised and 24 advanced). Lymphokine activated killer cell precursor (natural killer (NK) cell) activity was significantly diminished in patients with advanced tumours $(\mathrm{p}<0 \cdot 02)$ as was fully mature LAK cell activity against an NK resistant target cell $(\mathrm{p}<0.012)$. T-lymphocyte responses were not significantly different between the three groups. The reduced LAK cell generation was associated with a significantly diminished proliferative response of LAK precursors to stimulation with high dose IL-2 in vitro $(\mathrm{p}<0 \cdot 012)$. Impaired LAK cell generation may explain the failure of adoptive cellular immunotherapy with LAK cells in some patients with advanced gastrointestinal cancer and prompts the search for means of augmenting this activity in such patients.

\begin{abstract}
Recurrent tumours of gastrointestinal origin are frequently resistant to conventional treatment with radiotherapy or chemotherapy. The recent reports on the successful use of adoptive cellular immunotherapy in patients with advanced solid organ malignancy have, however, rekindled interest in this approach. ${ }^{\prime 2}$ The principle of this treatment is to incubate large numbers of the patient's lymphocytes with high concentrations of the T-cell derived growth factor Interleukin-2 (IL-2) in vitro for several days. This procedure yields a population of lymphoblasts which are highly cytotoxic against a wide variety of tumour cells, including autologous tumour, but not normal cells. These lymphokine activated killer (LAK) cells are then reinfused into the patient in high numbers together with IL-2 and have been shown to produce regression and in some cases cure, in most experimental animals and in a proportion of patients suffering from disseminated solid organ malignancy of a variety of origins. ${ }^{3.5}$
\end{abstract}

Address for correspondence: Mr P J Guillou, University Department of Surgery, St James's University Hospital, Leeds LS9 7TF.

Received for publication 25 May 1987
The almost universal success of this treatment in animals receiving syngeneic LAK cells (generated from healthy animals) contrasts with the failure of this treatment in about $50 \%$ of patients receiving autologous LAK cells. ${ }^{\circ}$ The study of these failures may provide insight into means of augmenting the efficacy of this procedure since we, and others, have previously shown that patients with advanced gastrointestinal cancer exhibit impaired specific and nonspecific immunological responses. ${ }^{78}$ More recently we have suggested that this may be a consequence of a failure of these patients' lymphocytes to generate adequate levels of the lymphokine IL-2." Interleukin-2 is known to positively regulate the expression of its own high affinity receptors ${ }^{11}$ and it may therefore be possible that LAK cell therapy fails in these patients because of their incapacity to generate a lymphocytotoxic response on exposure to exogenous lymphokine. The present investigations were designed to examine this possibility.

The term LAK cell is a functional denomination for cytotoxic lymphocytes whose phenotypic characteristics remain a matter of some controversy. Some workers suggest that LAK cell activity is subserved by lymphocytes whose precursors are natural killer 1420 
(NK) cells. ${ }^{12}$ Others claim that the precursors are of T-lymphocyte iineage although they do not bind the classical markers of cytotoxic T-lymphocytes. ${ }^{131+}$ In this study we have examined some functional attributes of both T-lymphocytes and NK cells as well as LAK cell activity in patients with gastrointestinal cancer. In addition lymphocyte proliferation in response to IL-2 has also been measured.

\section{Methods}

\section{PATIENTS}

Lymphocyte function was measured in three groups of individuals. Group 1 (controls) consisted of 44 patients suffering from non-malignant conditions (gall stones, peptic ulceration or peripheral vascular disease) admitted to the general surgical wards for operation. Forty four preoperative patients suffering from gastrointestinal cancer arising in the stomach, colon or rectum were also studied. Upon receipt of the surgical and pathological findings these patients were assigned either to the localised gastrointestinal cancer group (group 2) or were classified as suffering from advanced disease (group 3) without previous knowledge of the results of the lymphocyte function tests. Group 3 patients contained all those whose tumours were found to have breached the serosa or involved the regional lymph nodes, invaded local structures or had metastasised to the liver. Thus the only patients who were eligible for inclusion in group 2 were those with Dukes' stages A or B colorectal tumours or those with a mucosal gastric cancer. The final distribution of these patients is shown in the Table.

\section{LYMPHOCYTE PREPARATION}

Heparinised venous blood was obtained from all patients under study at the same time on the morning of operation before administration of any premedication. Peripheral blood mononuclear cells (PBMC) were obtained by Ficoll-hypaque centrifugation and corrected to a cell density of $1.5 \times 10^{7}$ cells $/ \mathrm{ml}$ in RPMI 1640 medium containing gentamicin $(160 \mu \mathrm{g} / \mathrm{ml})$, Amphotericin $(2.5 \mu \mathrm{g} / \mathrm{ml})$,

Table Details of patients

\begin{tabular}{|c|c|c|c|c|}
\hline & $n$ & $\begin{array}{l}\text { Mean age } \\
\text { (years) }( \pm s E)\end{array}$ & $M: F$ & Tumour site \\
\hline $\begin{array}{l}\text { Controls } \\
\text { Localised GI }\end{array}$ & 44 & $59 \cdot 5 \pm 2 \cdot 9$ & $29: 15$ & - \\
\hline cancer & 20 & $67 \pm 3 \cdot 1$ & 11: 9 & $\begin{array}{l}19 \text { colorectal } \\
1 \text { gastric }\end{array}$ \\
\hline $\begin{array}{l}\text { Advanced GI } \\
\text { cancer }\end{array}$ & 24 & $69 \pm 3 \cdot 2$ & $13: 11$ & $\begin{array}{l}11 \text { colorectal } \\
13 \text { gastric }\end{array}$ \\
\hline
\end{tabular}

glutamine $(2 \mathrm{mM})$ and $10 \%$ fetal calf serum (complete medium). These cells were then further diluted in complete medium for use in the following tests as described below.

BASAL NATURAL KILLER (NK) CELL ASSAY Natural killer activity was measured in these subjects using a four hour chromium release assay as previously described. ${ }^{15}$ The target cell used was the erythroleukemoid cell line K562. Briefly $5 \times 10^{5}$ PBMC were incubated with $10^{+}$st $\mathrm{ch}$ romium labelled K562 target cells in triplicate round bottomed microtitre plates in a total reaction volume of $200 \mu \mathrm{l}$ in complete medium. Serial doubling dilutions of the effector cells were done so that the effector:target ratios ranged from 50:1 down to $6 \cdot 25: 1$. After four hours' incubation at $37^{\circ} \mathrm{C}$ in a humidified atmosphere of $5 \% \mathrm{CO}_{2}$ in air, $100 \mu \mathrm{l}$ of the supernatant were removed from each well and counted for radioactivity in a gamma counter. Spontaneous ${ }^{51} \mathrm{Cr}$-release and maximal ${ }^{51} \mathrm{Cr}$ incorporation were obtained by incubating $10^{4}$ target cells alone in $200 \mu \mathrm{l}$ medium without any effector cells or in the presence of $100 \mu \mathrm{l}$ detergent respectively. The percentage specific ${ }^{5} \mathrm{Cr}$-release at each effector: target cell ratio was then calculated according to the usual formula:

$$
\frac{\text { Experimental release-spontaneous release }}{\text { Maximal release-spontaneous release }} \times 100
$$

\section{T-lymphocyte stimulation with Concanavalin- $A$}

Peripheral blood mononuclear cells at $10^{\hbar}$ cells $/ \mathrm{ml}$ were distributed in $200 \mu \mathrm{l}$ aliquots into 10 replicate wells of flat bottomed microtitre plates. Concanavalin A $(20 \mu \mathrm{g} / \mathrm{ml})$ was added to five of the wells and the plate was incubated at $37^{\circ} \mathrm{C}$ in a humidified atmosphere of $5 \% \mathrm{CO}_{2}$ in air for 48 hours, with ${ }^{3} \mathrm{H}$ thymidine $(1 \mu \mathrm{Ci} /$ well $)$ being added for the last 12 hours of culture. At the end of this period the cells were harvested and proliferation measured by counting the ${ }^{3} \mathrm{H}$-thymidine uptake in a beta counter. Thus for each patient studied the proliferation of unstimulated cells and Con-A stimulated cells was obtained in counts per minute and from these a stimulation index was calculated - that is,

$$
\mathrm{SI}=\frac{{ }^{3} \mathrm{H} \text {-Thymidine uptake in stimulated cells }(\mathrm{cpm})}{{ }^{3} \mathrm{H}-\text { Thymidine uptake in unstimulated cells }(\mathrm{cpm})}
$$

\section{IL-2 activation of $P B M C$}

For each individual 20 millilitres complete medium containing $1.5 \times 10^{6}$ PBMC per $\mathrm{ml}$ were prepared in $80 \mathrm{~cm}^{2}$ upstanding tissue culture flasks. To this cell suspension was added $200 \mathrm{units} / \mathrm{ml}$ of highly purified lectin free human lymphocyte derived Interleukin-2 (Lymphocult-HP, Biotest Pharma Gmbh, Frankfurt). This reagent is $95 \%$ pure and devoid of all biological activities attributable to interleukin 1 , 
Interferon, migratory inhibitory factor or colony stimulating factors. This concentration was chosen following preliminary dose-response studies of both LAK cell generation and lymphocyte proliferation. No consistent increase in LAK cell generation was observed with concentrations of IL-2 above $200 \mathrm{U} /$ $\mathrm{ml}$, whereas higher concentrations were associated with a lower cell yield and possible toxicity. The flasks were incubated for 72 hours, the cells being agitated for two minutes twice daily. At the end of the three day period the cells were harvested, corrected to a cell density of $5 \times 10^{6} / \mathrm{ml}$ and used in the assays of IL-2 activated cytotoxicity as detailed below. In addition, five replicate $100 \mu \mathrm{l}$ aliquots of this cell suspension were also incubated for a further 12 hours with $0.1 \mu \mathrm{Ci}$ of $\mathrm{H}$-thymidine for the assessment of IL-2 induced lymphocyte proliferation. These results are recorded as the mean ${ }^{3} \mathrm{H}$-thymidine uptake of 5 replicate wells in counts per minute.

Cytotoxicity assays for $I L-2$ activated PBMC

Interleukin- 2 activated PBMC at a cell density of $5 \times$ $10 \% / \mathrm{ml}$ complete medium were used as effector cells in four hour ${ }^{51}$ chromium release assays against two target cells in an identical manner to that described above for basal NK activity. The cytotoxicity of these lymphokine activated cells was measured against the NK sensitive cell line K562 and this is referred to as 'activated' NK activity. Lymphokine activated killer cell activity was also measured against the archetypal LAK cell target cell DAUDI. This is an NK-resistant lymphoblastoid cell line originating from a patient suffering from a Burkitt lymphoma and has not been found to be susceptible to any spontaneous allogeneic lymphocytotoxicity other than as a LAK cell target. ${ }^{1314}$

STATISTICAL ANALYSIS

All data are expressed as mean \pm SE for each group under consideration. Statistical analysis was by Student's $t$ test after logarithmic transformation to normalise the data.

\section{Results}

BASAL NK ACTIVITY (Fig. 1)

The mean basal NK activity exerted against the cell line $\mathrm{K} 562$ for all three study groups is summarised in Figure 1 . The mean $( \pm \mathrm{SE})$ percentage cytotoxicity of control lymphocytes at an effector:target cell ratio of $50: 1$ was $32 \cdot 1 \pm 2 \cdot 26 \%$. This was not significantly different from the corresponding mean figure of $37.7 \pm 3.98 \%$ for lymphocytes from the patients suffering from localised gastrointestinal cancer $(t=1 \cdot 3, p=0 \cdot 099$, NS $)$. The mean NK activity in control subjects, however, was significantly higher

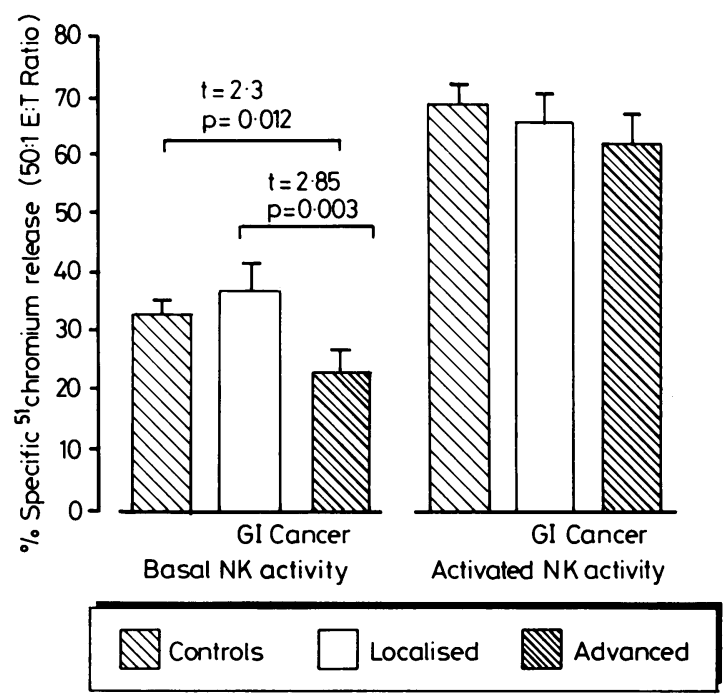

Fig. 1 Basal and IL-2-activated cellular cytotoxicity against the natural killer cell target $K 562$ in controls and patients suffering from gastrointestinal cancer.

than that of patients suffering from advanced gastrointestinal cancer $(23 \cdot 25 \pm 3 \cdot 2 \%, t=2 \cdot 3, p=0 \cdot 012)$ as was that of the patients suffering from localised disease $(t=2 \cdot 85, p=0 \cdot 0034)$.

\section{IL-2 ACTIVATED LYMPHOCYTOTOXICITY} AGAINST K562. (ACTIVATED NK ACTIVITY)

At an effector:target cell ratio of 50:1 the mean activated NK activity against the K562 cell line was $69 \cdot 1 \pm 4 \cdot 36 \%$ for control subjects, $66 \cdot 2 \pm 4 \cdot 36 \%$ for patients with localised disease and $62 \cdot 1 \pm 4 \cdot 17 \%$ for patients with advanced GI cancer. None of these figures was significantly different from one another (Fig. 1).

\section{LYMPHOCYTE PROLIFERATION}

Figure 2 reveals that the ${ }^{3} \mathrm{H}$-thymidine uptake of unstimulated lymphocytes from all three patient groups were not significantly different from one another indicating no increase or decrease in spontaneous lymphocyte proliferation in any of the three groups. Although there was a trend towards lower Concanavalin-A stimulated lymphocyte proliferation in the two cancer groups the mean responses were again not significantly different from those seen in the control subjects. This also is the case when these data are expressed as a stimulation index.

These observations are in marked contrast to the proliferative responses observed for the lymphocytes exposed to pure IL-2 alone in vitro (Fig. 3). The mean ${ }^{3} \mathrm{H}$-thymidine uptake (expressed as $\mathrm{cpm} \times 10^{-3}$ ) for lymphocytes from control subjects was $25 \cdot 176 \pm 2 \cdot 743$ 


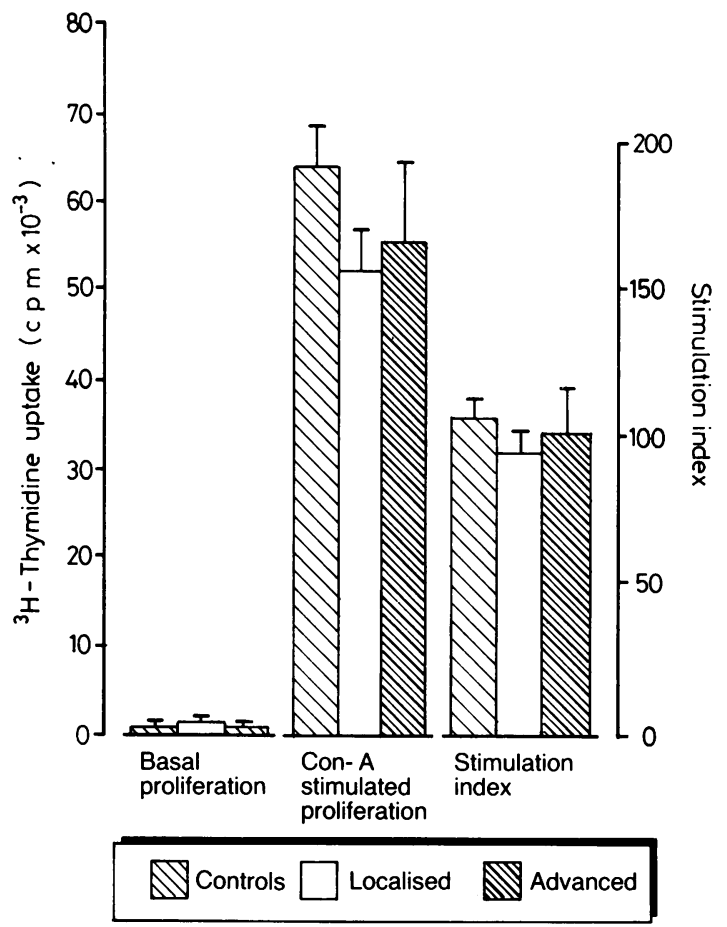

Fig. 2 Spontaneous (basal) proliferation, lectin (Con A) stimulated proliferation and stimulation indices of control subjects and patients suffering from gastrointestinal cancer.

and was not significantly different from the figure of $27 \cdot 365 \pm 5 \cdot 82$ observed for the patients with localised cancer $(t=0 \cdot 22, p=0 \cdot 414)$. The corresponding mean ${ }^{3} \mathrm{H}$-thymidine uptake of cells from patients with advanced GI cancer was $13 \cdot 74 \pm 2 \cdot 52$, this being significantly lower than that obtained for control subjects $(t=2.59, p=0.007)$ as well as that obtained for the patients with localised gastrointestinal cancer $(\mathrm{t}=2 \cdot 0795, \mathrm{p}=0 \cdot 025)$.

LYMPHOKINE ACTIVATED KILLER (LAK) CELL ACTIVITY

The mean ( \pm 2 SE) LAK cell activity at an effector:target cell ratio of 50:1 for each of the three subject groups is also displayed in Figure 3. The mean LAK cell activity exerted by IL- 2 stimulated lymphocytes from control subjects was $25 \cdot 8 \pm 2 \cdot 42 \%$ compared with a mean figure of $30 \cdot 83 \pm 4.25 \%$ for lymphocytes from patients with localised GI cancer $(t=0.715, p=0 \cdot 24)$. In contrast the mean LAK activity for the lymphocytes obtained from patients suffering from advanced GI cancer was $16 \cdot 8 \pm 4 \cdot 23 \%$ which was significantly lower than both that of the control group $(t=3 \cdot 87, p=0 \cdot 0001)$ and of those with localised disease $(t=2 \cdot 33, p=0 \cdot 012)$.
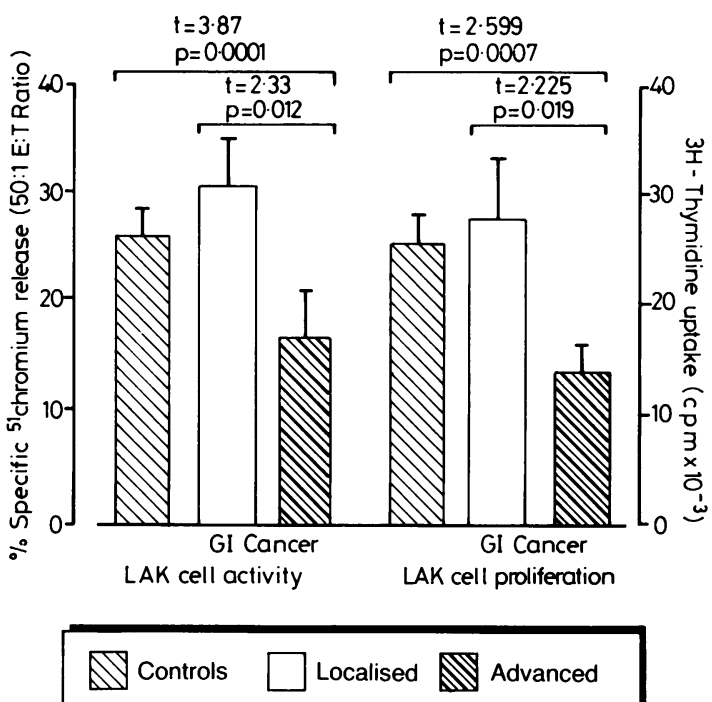

Fig. 3 Cytotoxic activity and proliferation of lymphokine activated killer ( $L A K)$ cells in control subjects and patients suffering from gastrointestinal cancer.

\section{Discussion}

The upsurge of interest in the LAK cell phenomenon results from the fascinating results which have been claimed for adoptive cellular immunotherapy using autologous LAK cells in patients suffering from solid organ malignancies which have proved resistant to all other types of therapy. ${ }^{16}$ This approach has evolved from the results of exhaustive experimental animal studies which have used LAK cell infusions derived from non-tumour bearing animals and in such systems complete regression of tumour metastases has been repeatedly shown..$^{3-5}$ This contrasts with clinical experience where although partial, and occasionally, complete regression of solid tumour metastases are seen, a number of patients with advanced tumour burdens seem not to respond to autologous LAK cell therapy. ${ }^{1616}$ The experimental models clearly do not wholly reflect the clinical scenario and thus before this treatment is widely attempted, further information on the capacity of patients with heavy tumour loads to generate adequate LAK cell cytotoxicity is required.

Several workers have previously described abnormalities in NK cell function in patients suffering from malignant disease ${ }^{17-19}$ This is important because of the widely held view that NK cells are the main precursors of LAK cell activity." "' Our results on basal NK activity are in keeping with previous studies in gastrointestinal cancer patients and may partially explain the diminished LAK cell activity seen in our patients with advanced gastrointestinal cancer. It is 
noteworthy, however, that even though the NK activity is diminished in patients with advanced disease, lymphokine activated killing of the NKsusceptible target cell $\mathrm{K} 562$ is almost identical in all three groups and suggests that these patients at least have the potential to generate higher levels of lymphocytotoxicity even if this is relatively diminished when these stimulated cells are confronted with an NK-resistant target cell - that is, exert impaired LAK activity.

An alternative view of LAK cell precursors is that they represent a T-lymphocyte which is quite distinct from classical cytotoxic T-lymphocytes. ${ }^{1314}$ If a generalised T-cell defect does exist in these patients, then this may also partially explain the failure of LAK cell generation in our group of patients with advanced disease. In the present study the proliferation of unstimulated T-cells is similar in all three groups but, although not statistically significant, the response to a T-cell mitogen is on average diminished in the two cancer groups. We have previously shown that a helper T-cell defect exists in these patients," and this may well influence other T-cell functions including T-cell-mediated LAK activity. As IL-2 stimulated LAK cell activity is derived from the proliferation of NK-like cells and T-cells after exposure of their IL-2 receptors to a high local concentration of IL-2, we have also examined the proliferation of LAK precursor cells during the LAK cell generation phase. It is evident that the ${ }^{3} \mathrm{H}$-thymidine uptake by these cells during the three day incubation period with IL-2 is markedly diminished in those patients suffering from advanced disease. Considering all these data as a whole, therefore, we would suggest that the reported failure of LAK cell therapy to influence the course of the disease in some patients with advanced gastrointestinal malignancy is because of an inherent incapacity of these patients to generate adequate LAK cell cytotoxicity in the in vitro induction phase. Furthermore, the results presented in this study would incline to the conclusion that this is attributable to the presence of a diminished proliferative capacity of LAK cell precursors.

It is possible that this reduced IL-2-activated lymphocyte proliferation is attributable to diminished numbers of either the T-cell or NK cell component of LAK precursors. We have previously reported," however, that patients suffering from advanced gastrointestinal cancer possess normal numbers of lymphocytes expressing the CD3 (pan T-cell) marker. Similarly there is no convincing evidence that circulating NK cell numbers are diminished in patients with advanced maligancies including colorectal cancer. ${ }^{192}$ Despite impaired basal NK activity we have found that activated cytotoxicity against the NK target cell $\mathrm{K} 562$ is normal in the advanced cancer patients in this investigation. Overall, therefore, our data tend to the conclusion that it is a defect in the T-cell component of LAK precursors which is responsible for the impaired LAK activity which we report in the advanced cancer group. In view of the impaired basal NK activity in these patients, however, a proliferative and cytotoxic defect in this component of LAK activity cannot be excluded.

In conclusion, this investigation has revealed that LAK activity in patients with advanced gastrointestinal cancer is impaired compared with that observed in patients with localised disease and healthy control subjects. This impaired activity is associated with diminished proliferation of LAK precursors and may explain the failure of LAK/IL-2 therapy in patients with advanced gastrointestinal cancer. Further studies are required to dissect this defect in greater detail, with a view to identifying means of augmenting LAK activity in therapeutic protocols.

J R T Monson was supported by a grant from Geistlicht Sons, Chester. The Special Trustees of the hospitals of the Leeds Eastern Health Authority generously provided funding for the continued support of this work. We are grateful to Mrs I Poole for her secretarial assistance.

\section{References}

1 Rosenberg SA, Lotze MT, Muul LM, et al. Observations on the administration of autologous lymphokineactivated killer cells and recombinant Interleukin-2 to patients with metastatic cancer. $N$ Engl J Med 1985; 313: 1485-92.

2 Ohuno K, Takagi H, Nakamura T, Nakamura Y, Iwasa $\mathrm{Z}$, Yasutomi M. Treatment for unresectable hepatoma via selective hepatic arterial infusion of lymphokineactivated killer cells generated from autologous spleen cells. Cancer 1986; 58: 1001-6.

3 Lafreniere R, Rosenberg SA. Successful immunotherapy of murine experimental hepatic metastases with lymphokine-activated killer cells and recombinant Interleukin 2. Cancer Res 1985; 45: 3735-41.

4 Mule JJ, Ettinghausen SE, Spiess PJ, Shu S, Rosenberg SA. Antitumour efficacy of lymphokine-activated killer cells and recombinant. Interleukin-2 in vivo: Survival benefit and mechanisms of tumour escape in mice undergoing immunotherapy. Cancer Res 1986; 46: 67683.

5 Forni G, Giovarelli M, Santoni A. Lymphokine activated tumour inhibition in vivo $I$. The local administration of Interleukin-2 triggers nonreactive lymphocytes from tumour-bearing mice to inhibit tumour growth. J Immunol 1985; 134: 1305-11.

6 Rosenberg SA, Lotze MT, Muul LM, et al. A progress report on the treatment of 157 patients with advanced cancer using lymphokine-activated killer cells and Inter- 
leukin-2 or high-dose Interleukin-2 alone. $N$ Engl J Med 1987; 316: 889-97.

7 Guillou PJ, Giles GR. Inhibition of leucocyte migration by tumour-associated antigens of the colon and rectum. Gut 1973; 14: 733-8.

8 Guillou PJ, Brennan TG, Giles GR. A study of lymph nodes draining colorectal cancer using a two-stage inhibition of leucocyte migration technique. Gut 1975; 16: $290-7$.

9 Monson JRT, Ramsden CW, Guillou PJ. Decreased Interleukin-2 production in patients with gastrointestinal cancer. Br J Surg 1986; 73: 483-6.

10 Wakasugi H, Bertoglio J, Tursz T, Fradelizi D. IL-2 receptor induction on human T-lymphocytes: role for IL-2 and monocytes. $J$ Immunol 1985; 135: 321-5.

11 Itoh K, Tilden AB, Kumagai K, Balch CM. Leu-11 ${ }^{+}$ lymphocytes with natural killer (NK) activity are precursors of recombinant Interleukin-2 (rIL-2)-induced activated killer (AK) cells. $J$ Immunol 1985; 134: 802-7.

12 Phillips JH, Lanier LL. Dissection of the lymphokineactivated killer phenomenon. Relative contribution of peripheral blood natural killer cells and T lymphocytes to cytolysis. J Exp Med 1986; 164: 814-25.

13 Grimm EA, Ramsey KM, Mazumder A, Wilson DJ, Djeu JY, Rosenberg SA. Lymphokine-activated killer cell phenomenon. II. Precursor phenotype is serologically distinct from peripheral $\mathrm{T}$ lymphocytes, memory cytotoxic thymus-derived lymphocytes and natural killer cells. J Exp Med 1983; 157: 884-97.
14 Ortaldo JR, Mason A, Overton R. Lymphokine-activated killer cells: analysis of progenitors and effectors. J Exp Med 1986; 164: 1193-205.

15 Guillou PJ, Giles GR, Ramsden CW. Natural killer cell activity, Interferon alpha ${ }_{2}$ production and Interleukin-2 production in Cyclosporine-treated and conventionally immunosuppressed human allograft recipients. J Clin Immunol 1986; 6: 373-80.

16 West WH, Tauer KW, Yannelli JR, et al. Constantinfusion recombinant Interleukin-2 in adoptive immunotherapy of advanced cancer. $N$ Engl J Med 1987; 316: 898-905.

17 Balch CM, Tilden AB, Dougherty PA, Cloud G, Abu T. Depressed levels of granular lymphocytes with natural killer (NK) cell function in 247 cancer patients. Ann Surg 1983; 198: 192-9.

18 Uchida A, Colot M, Michsche M. Suppression of natural killer cell activity by adherent effusion cells of cancer patients. Suppression of motility, binding capacity and lethal hit of NK cells. Br J Cancer 1984; 49: 17-23.

19 Steinhauer EH, Doyle AT, Reed J, Kadish AS. Defective natural cytotoxicity in patients with cancer: normal number of effector cells but decreased recycling capacity in patients with advanced disease. J Immunol 1982; 129: 2255-9.

20 Balch CM, Tilden AB, Dougherty PA, Cloud GA, Abo T. Heterogeneity of natural killer lymphocyte abnormalities in colon cancer patients. Surgery 1984; 95: 63-9. 